\title{
Tarihsel Süreç İçinde Kent Kimliğinin Mekânsal Kalite Değerlendirmesi Üzerine Bir Araştırma (Taksim Meydanı)
}

\author{
Hande Sanem ÇINAR ALTINÇEKİÇ, Berna ERGİN, Merve TANFER \\ İstanbul Üniversitesi Orman Fakültesi Peyzaj Mimarlığı Bölümü, İstanbul \\ Eser Bilgisi: \\ Araştırma makalesi \\ Sorumlu yazar: Hande Sanem ÇINAR ALTINÇEKIÇ, e-mail: saneme@istanbul.edu.tr \\ doi: http://dx.doi.org/10.17474/acuofd.26010
}

\section{ÖZET}

Taksim Meydanı, Cumhuriyet dönemi anıları üzerine inşa edilmesi ile kentli belleğinde yerleşmiş, insanların buluştuğu enerji merkezi ve önemli bir kentsel odaktır. Tarihinden günümüze geçen süreç içinde, gelişen teknoloji ile hızla büyüyen kentin, ihtiyaçlarını karşılamak için çevresiyle olan etkileşiminin göz önüne alınmadan gelişmesi, nüfus ile orantılı olarak artan araç trafiği ve yapılan düzenlemeler, meydanı kavşağa dönüştürmüş ve kimliğini kaybetme ile karşı karşıya gelmiştir. Çalışmada, son dönemlerde çok konuşulan ve çeşitli düzenlemelerle değişime uğratılmaya çalışılan Meydan ve çevresinin kimliği, tarihsel değişim sürecinden yola çıkıp mekânsal kalite parametreleri açısından irdelenerek günümüzde yenileme projesinin kent kimliğine etkileri değerlendirilecektir.

Anahtar kelimeler: Mekân, Kentsel Mekân, Taksim Meydanı, Kent Kimliği.

\section{A Study on the Evaluation of City Identity in Terms of Spatial Quality Throughout History (Taksim Square)}

\section{Article Info:}

Research article

Corresponding author: Hande Sanem ÇINARALTINÇEKIÇ, e-mail: saneme@istanbul.edu.tr

\section{ABSTRACT}

Taksim square is an energy center that people meet, and a significant urban focus which has found an important place on people's mind thanks to its association with memories of the Republican Era. Throughout history the regulations has been made to control the fast growing vehicle traffic, which has been increasing in relation to population rate, and the enhancements done to meet necessities of the fast growing city parallel to the improving technology, without considering its interaction with environment, converts the square into an intersection and now it is about to lose its identity. In this study, the identity of the square and its surrounding, which has been discussed and attempted to be modified with various regulations, is discussed in terms of spatial quality parameters by starting the process of historical change and the effects of the current renewal of the square is evaluated.

Keywords: Space, Urban space, Taksim Square, City Identity

\section{Giriş}

Kentsel mekânlar, mekânı kullanan kullanıcıların kültürel birikimlerini paylaştığı ve birbirleriyle etkileşimleri sonucu kentli olma deneyiminin elde edildiği (İnceoğlu 2007), kentin ana bütünleşme aracıdır. Kente ait mekânların özellikle meydanların etkili bir biçimde 
kullanımı, 'mekân kalitesinin' göstergeleri olarak düşünülebilir. Zucker (1959) 'a göre; Kent meydanları, tarih boyunca kentlerimizin kimliğini ve kişiliğini ortaya koyan önemli bir kentsel yaşam odağıdır. Türkiye'nin gelişme sürecinde yaşadığ hızlı kentleşme olgusuyla birlikte kentler sürekli büyümekte ve nitelik değiştirmektedir (Karagözlü,2013). Bu nedenle kent meydanları, tarih boyunca kentlerimizin kimliğini ortaya koyan önemli bir kentsel odak iken, günümüzde taşıt trafiğini hafifleten kavşak veya otopark olarak kullanılarak özgün değerlerini yitirme yolunda ilerlemektedir.

Her insanın kendine ait özellikleri, kimliği ve kişiliği olduğu gibi kentlerin de kendilerine ait kimlik ve kişilikleri vardır (Sağsöz Velioğlu ve Zorlu 1996). Kentsel kimliğin güçlendirilmesine ilişkin elemanlar konusunda her zaman ortak değerler ve toplumsal bir uzlaşı olduğuna inanan Lynch (1960), ilk olarak, "okunabilirlik" (legibility) kavramına göre odaklanmıştır. Tekeli (1990)'nın de belirttiği gibi 'Kimlik elemanları, kentsel algilama ve kent imajının esas belirleyicileridir. Lynch (1960), kimlik elemanların 5 farklı grupta toplamaktadır (Turan, 2010): Kent imajinın en baskın elemanı olan Yollar (Paths),Kent silüetini ya da bölgeler arası geçişi netleştirilen Sinırlar (Edges), Kentin fiziksel özellikler sergileyen sanayi, konut, ticari vb. Bölgeler (Districts), Meydanlar, kavşaklar gibi yoğun etkinlik merkezleri Düğüm noktaları (Nodes), Dikkat çekici obje ya da mekanlar Odak noktaları (Landmarks)dir. Sembol olarak bölgenin odağı veya ta kendisidir (İstanbul-Taksim meydanı gibi) (Deniz, 2011).

Kent kimliği, kentin imgesini etkileyen; her kentte farklı ölçek ve yorumlarla kendine özgü nitelikler taşıyan; fiziksel, kültürel, sosyo-ekonomik, tarihsel ve biçimsel faktörlerle şekillenen; sürekli gelişen ve sürdürülebilir kent kavramını yaşatan, geçmişten geleceğe uzanan büyük bir sürecin ortaya çıkarttığı anlam yüklü bütünlüktür (Çöl 1998). Aynı zamanda değişik kültür katmanlarının üst üste birikmesiyle oluşmuş, zaman içinde fiziksel, nüfus, teknolojik gelişim, yasal ve yönetsel süreç vb. nedenlerle değişime uğrayan (Deniz 2011) dinamik bir süreçtir. $\mathrm{Bu}$ dinamik süreçte kentsel mekânlar; tasarımin ekonomik rasyonellik baskısı altında kalmakta ve kent kültürünün (kentli olma bilinci, gelenek vb.) unutulmasıyla kimliksiz, niteliksiz mekânlar ortaya çıkmaktadır (Özer ve Ayten 2005).

\section{MATERYAL ve YÖNTEM}

Çalışma konusu olan Taksim Meydanı, Cumhuriyet dönemi anıları üzerine inşa edilmiştir. Gelişen teknoloji ve buna bağlı olarak hızla büyüyen kentin ihtiyaçlarını karşılamak için ulaşım ağının çevresiyle olan etkileşimi ile meydan, kavşağa dönüşmüsstür (Şekil 1) . Bir asırlık zaman diliminde farklı işlevlere sahip, farklı sosyal ve fiziksel kimliği ile bugüne ulaşan (Gürsel 2012) meydan, günümüz koşullarında can çekişmektedir. Çözümü için önerilen yayalaştırma projeleri arasında, kent dokusunu korumak ve tarihi yaşatmak amacıyla Topçu Kışlasının tekrar inşası, ticari ve kültürel olarak hizmet vermesi, ardından farklı bir projede meydanın devasa bir sert zemin yapılması gündeme gelmiştir. Kent kimliğini güçlendirme ve yayalaştırma projesiyle teoride bir bütünlük içinde bulunan bu fikirler, geçen süreçte değişen sosyal ve fiziksel koşullar değerlendirildiğinde (Çalışkan 2011), toplumun ihtiyaçlarını karşılama ve çevresi ile oluşacak etkileşimi bakımından, mekânsal kalite bağlamında titizlikle ele alınmalıdır. Bu çalışmada Taksim Meydanında değişik kültür katmanlarının değişime uğrayan dinamik sürecinde mekânsal kalite değişimleri ve 
günümüz meydanında öneri projelerin kent kimliğine yansımaları irdelenecektir.

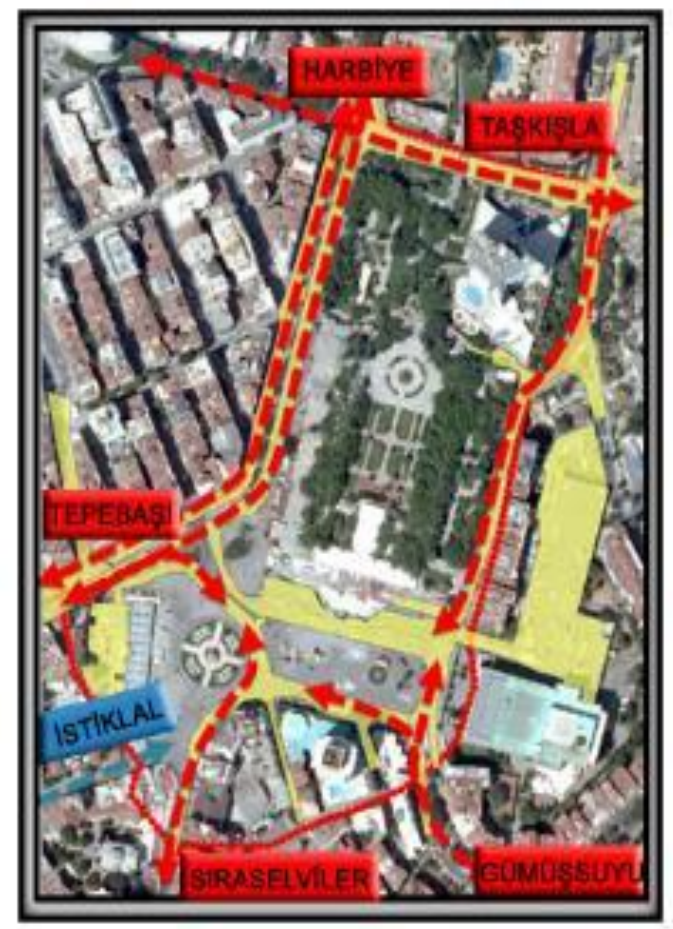

Şekil 1. Meydan çevresi ve akslar (Yalçın, 2011 ).

Çalışma kapsamında; Literatür araştırması ile Meydan ve çevresi için hazırlanan haritalardan yararlanılarak 1806 yılından bugüne gelişim ve değişimler saptanarak, dönemlerine göre 'Mekânsal Kalite Parametreleri' yardımıyla analiz edilecektir.

Mekânsal kalite; tasarımda fark edilen, göze çarpan farklılıklar olarak ele alınmaktadır (Rapoport 1977). Gibson'a (1968) göre, mekânsal kalite özünde göze çarpan farklılıklar arka plandakiler ile ilgilidir. Yani bu farklılıkların alanda yer alan düzenin yapım aşamasındaki durumundan itibaren başlayıp değişikliklere uğraması mekânsal kalitenin okunabilirliğini sağlayacağını belirtmiştir. Bu yüzden araştırma alanının oluşumundan itibaren günümüze gelene kadar geçen evredeki değişiklikler haritalar üzerinde okunabilirliği irdelenecektir.
Taksim meydanında tarihsel süreç içinde kentsel kimliğini incelemek için kullanılacak olan mekânsal kalite parametreleri oluşturulurken, İnceoğlu (2007), Lynch (1960) Voordt (2005) , Anonim (2000)'in konu ile ilgili çalışmaları incelenmiştir

Rapoport (1977)'a göre; tasarımda fark edilen, göze çarpan farklılıklar ve bilgiler ele alınarak, tarihten günümüze mekansal kalite parametre (Tablo 1) değerlendirmesi gerçekleşmiştir. Parametrede yer alan 'işçilik' parametresi ve Bakım ve Hizmet Kalitesi parametresi, 1806-1925, 19251944, 1944-1987 y1llarında, tarihi bilgi ve belge yetersizliği nedeniyle değerlendirilmeye alınmamıştır. Çeşitli çalışmalarda kullanılan ölçütlerin incelenmesi sonucunda, çalışma alanı olan Taksim Meydanı'nın düzeninin yıllara göre karşılaştırılması için kullanılacak olan ölçütler; Ulaşılabilirlik, Erişilebilirlik, Çeşitlilik, Esneklik, Güvenlik, Mekânsal Bütünlük, Konfor, Sürdürülebilirlik, Düzen, Kimlik, Etki-Çekim, Yapım Kalitesi, Bakım ve Hizmet Kalitesi olarak belirlenmiştir. Çalışmada ölçütlere ' +2 , $+1,-1,-2$ ' değerleri verilerek olumlu ve olumsuz etkenlerin arasındaki fark vurgulanmıştır. ' +2 ' değeri istenen özelliklerin sağlanmış olduğunu, '-2' ise istenen özelliklerden hiçbiri ya da bir kaçının sağlandığı durumları ifade etmektedir. Sonuç olarak yıllara göre alınan değerler toplanarak, en yüksek değer mekânsal kalite bağlamında istenen özelliklere en yakın düzenini gösterecektir.

\section{BULGULAR}

\section{Tarihte Meydan}

Taksim'de dönemin önemli yapılarından biri olan Topçu Kışlası, günümüzde 'Gezi Parkının' bulunduğu geniş alana 1806 yılında III. Selim tarafindan inşa ettirilmiştir. Kışlanın yapıldığı dönemde 
Beyoğlu bölgesi ve Taksim, kent merkezinden uzak, mezarlıkların bulunduğu ıssız bir alandı (Url 1). 1864'de Taksim ve Pangaltı arasındaki yol inşa edilmiş, ilerleyen yıllarda bu yol üzerinden Şişli'ye kadar uzanan atlı tramvay hattı hizmete girmiştir. 1870 yılında kışlanın arka tarafina Beaux-arts ilkelerine göre Osmanlının ilk kamusal parkı tasarlanmıştır (Kırmızı ve Çalışkan, 2009). 1918 yılında I. Dünya savaşında İstanbul'un işgalinden sonra kışla binası Fransızlar tarafindan kullanılmıs, bu dönemde Topçu Kışlası ve Talimhane meydanında çeşitli etkinlikler düzenlenmiştir. 1921'de işlevini yitiren Kışlanın avlusu stadyum olarak düzenlenmiş ve yıkıldığı döneme kadar bu şekilde kullanılmıştır. Taksim Meydanı'nın düzenlemesi 1928 yılında Topçu Kışlası'nın ahırlarının yıkılarak Cumhuriyet Anıtı'nın yerleştirilmesiyle başlamıştır (Kozar,2012). Bu dönemde Taksim'den bazı semtlere otobüs hatları hizmete girmiştir (Kırmızı ve Çalışkan 2009). 1933 yılında Elgötz’ün hazırladığı planda İstiklal Caddesi'nde iş ve ticaret işlevine ağırlık verilmesini, Taksim ile Galatasaray arasının kültürel işlevlerle donatılmasını, Taksim-Harbiye arasındaki Ermeni mezarlığının park haline getirilmesini önermiştir (Şekil 2) (Anonim 1987).

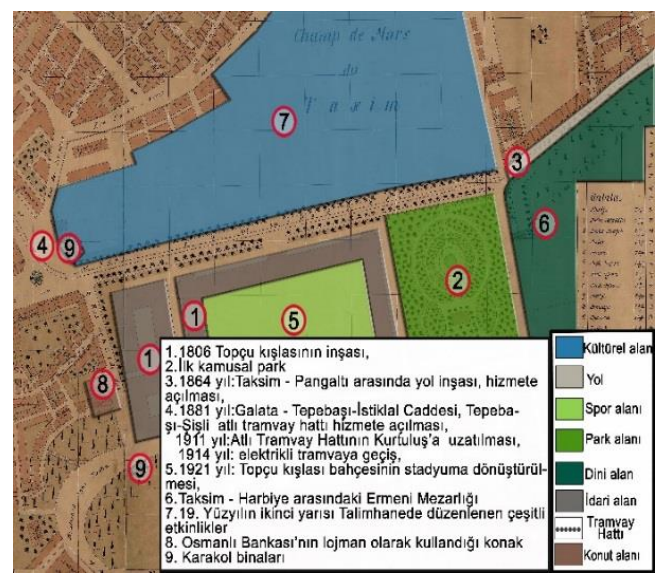

Şekil 2. 1806-1925 Yılına ait Kullanım Planı (Anonim 2001)'den uyarlanmıştır. 1936'da Şehir plancisı Henry Prost'un hazırladığı İstanbul Nazım İmar planında, Taksim Gezisi ile başlayıp Maçka'ya uzanan ve alt seviyede Dolmabahçe ile sinırlanan bir konferans vadisi olarak planlamış, kışlanın bulunduğu alan parkın başlangıç noktası olarak seçmiştir(Anonim 2012). Bu kapsamda kışlanın yıkılması öngörülmüsstür. 1940 yılında kışla dört parçaya ayrılarak yıkılmış, 1942'de 26.000 m2 yeşil alan ile park halkın hizmetine girmiştir (Kozar,2012). 1944 yılında alanın imara açılması ile Talimhane bölgesi parsellere ayrılmış ve modern konut inşası başlamıştır (Şekil 3).

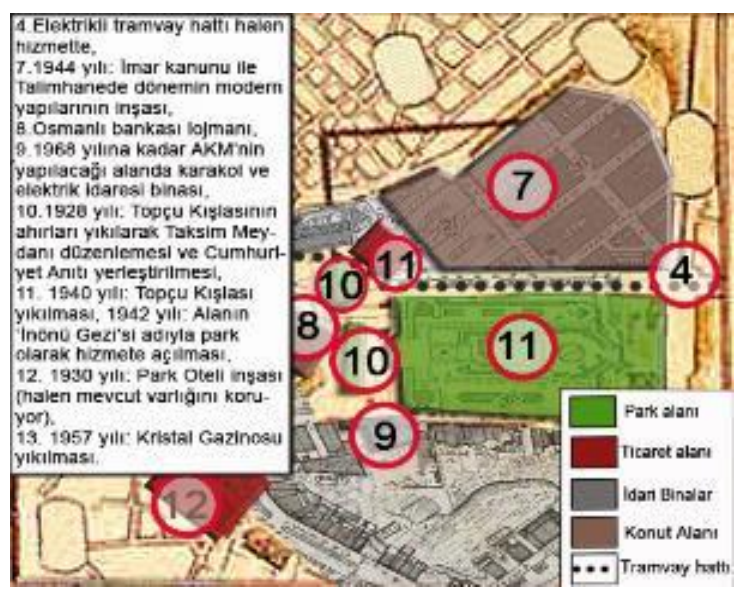

Şekil 3. 1925-1944 Yılı Kullanım Planı (Anonim 2001)'den uyarlanmıştır.

1955 yılında yaşanan 6-7 Eylül olaylarından sonra bölgede yaşayan azınlıklar yaşam alanlarını terk etmeye başlamıs, terk edilen yapılar alt gelir grubundaki ve göç edip gelen insanlara ev sahipliği yapmaya başlamıştır (Emir 2008). 1957 yılında meydanın çevresini açmak amacıyla imar operasyonları kapsamında Kristal gazinosu yıkılmıştır. 1968 yılında Elektrik idaresi ve karakol binasının bulunduğu alanda Atatürk Kültür Merkezinin temelleri atılmış ve 1969 yılında hizmete girmiştir (Kırmızı ve Çalışkan 2009). 
Bu dönemden sonra hala varlığını koruyan büyük otellerin inşası başlamış, bunun yanı sıra konut inşaatları da çoğalmıştır. Azınlıkların terk ettiği alanlar işyeri olarak kullanılmaya başlamıştır (Emir 2008).

1986-88 yılları arasında Tarlabaşı Caddesinde nitelikli yapıların yıkılması ile Tarlabaşı Bulvarı açılmıştır. Amaç bölgeyi Taksim Meydanı ile bağlantılı bir 'Açık Hava Müzesi' yapmak iken alanın Taksim'den tamamen kopmasina neden olmuştur . 1989 yilında Harbiye Cemal Reşit Rey salonunun yapılması ile kültür faaliyetleri gelişmeye başlamıştır.(Şekil 4).

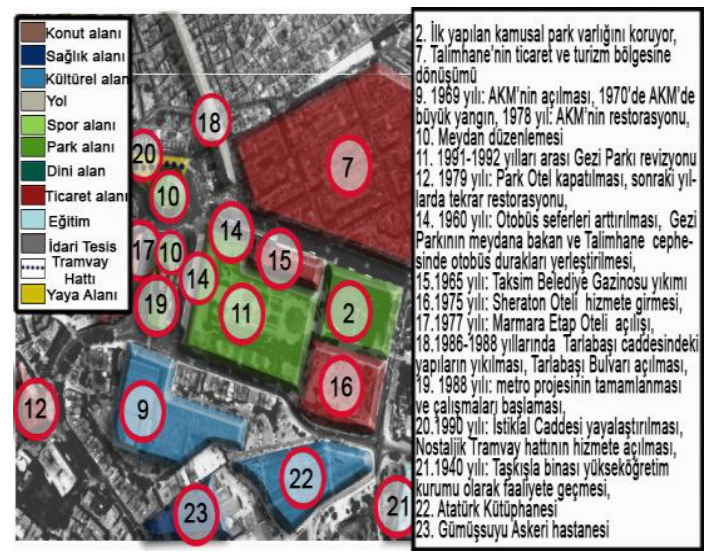

Şekil 4. 1944-1987 Yılı kullanım planı (Ur12) ten uyarlanmıştır.

1990 yilında trafiğin yoğunluğu nedeniyle İstiklal Caddesi yaya bölgesine dönüştürülmüş ve Nostaljik Tramvay hizmete girmiştir (Kırmızı ve Çalışkan 2009). 2000'li y1llarda Talimhane bölgesindeki dönemin modern yapıları, oteller bölgesi haline gelmiştir (Emir 2008). Bölgedeki konutların büyük bir çoğunluğu işyeri olarak hizmet etmeye başlamıştır. Taksim-4.Levent Metrosu hizmete açılmıştır. Metro ağı hem Şişhane hem de Haciosman'a kadar ilerletilmiş, Kabataş füniküler sistemi hizmete açılmıştır. Taksim meydanı ulaşımın merkezi haline gelmiştir (Şekil 5).

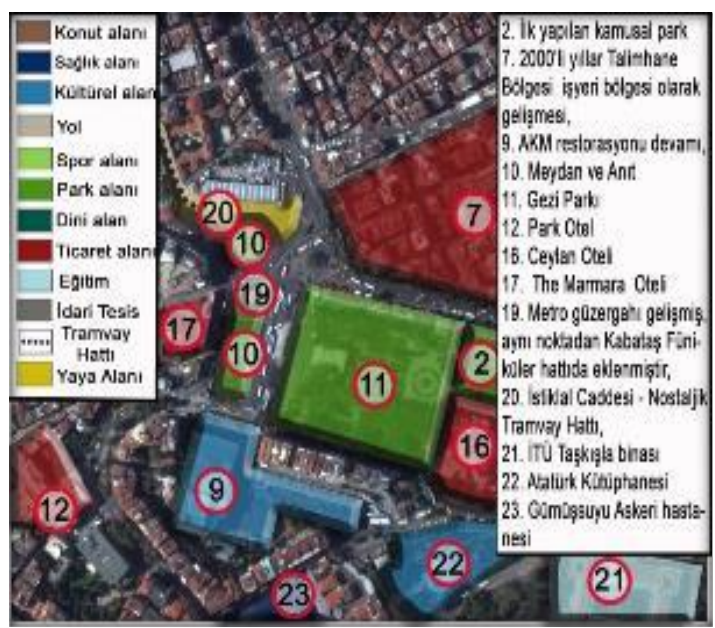

Şekil 5. 1987- 2014 kullanım planı (Url 3)ten uyarlanmıştır.

\section{Mekânsal Kalite Parametreleri Açısından Haritaların İncelenmesi}

\section{6-1925 Yilına Ait Değerlendirme}

\section{İşlevsel Kalite Kullanım ve Eylemler}

Ulaşılabilirlik: Alan, bu dönemde kent merkezinden uzakta kalmaktadır. Talimhane bölgesi meydan işlevi görmektedir (Kozar,2012). 1881'de atlı tramvay, 1914 yılında elektrikli tramvay hizmete girmiştir (Kırmızı ve Çalışkan 2009).

Erişilebilirlik: Kışlanın yakın çevresinde yer alan İstiklal Caddesi, Gümüsssuyu, Harbiye aksları erişilebilirlik açısından en önemli akslardır.

Çeşitlilik: 1921 yılından sonra Kışla'nın avlusu spor aktiviteleri için kullanılmıştır (Kozar, 2012). Ayrıca Topçu Kışlasının yakın çevresinde bu dönemde ibadet alanları, hastane ve binalar, okullar, su maksemi, Osmanlı Bankasına ait konak ve Pera'daki cafe ve eğlence yerleri bulunmaktadır (Eryılmaz 1999).

Esneklik: Kışla yapıldığı dönemde amacına hizmet ederken, 1.Dünya Savaşı sırasında 
işgalci kuvvetlere ev sahipliği yapmıştır. Daha sonra yapinın tahrip olmasından dolayı avlu stadyum olarak düzenlenmiştir. Ayrica yapı, alt gelir gruplarına barınma imkânı da sağlamıştır.

Güvenlik: Alanda askeri bina ve iki karakol bulunmaktadır. Osmanlı yönetimi Müslümanların eğlenmelerini, içki içmelerini yasaklamış ve girişler polis denetimine alınmıştır (Eryılmaz 1999).

Mekânsal Bütünlük: Kışlanın yapıldığı dönemde ve onu takip eden süre içinde bölgede inşaat yapımının yasak olmasından dolayı yapının etrafinda boş alanlar mevcuttur. $\mathrm{Bu}$ dönemde mekansal bütünlük söz konusu değildir.

Konfor: Kışlanın arkasında bulunan Osmanlı döneminin ilk kamusal parkı halkın konforlu ve gözde gezinti yeri haline gelmiştir (Eryılmaz 1999).

Sürdürülebilirlik: Bölgedeki mezarlıklar kaldırılıp, yerine kışla binası ve park yapılandırıldığından, alanda büyük ölçüde fiziksel değişimler söz konusu olmuştur. Sonuç olarak sürdürülebilirlikten bahsetmek de mümkün değildir.

Tablo 1 Mekansal Kalite Parametreleri (İnceoğlu, 2007 ve Voordt 2005)

\begin{tabular}{|c|c|c|c|}
\hline $\begin{array}{l}\text { İşlevsel Kalite } \\
\text { Kullanım Ve Eylemler }\end{array}$ & $\begin{array}{l}\text { Estetik } \\
\text { Kalite }\end{array}$ & Yapım Kalitesi & $\begin{array}{l}\text { Bakım Ve Hizmet } \\
\text { Kalitesi }\end{array}$ \\
\hline $\begin{array}{l}\text { Ulaşılabilirlik } \\
\text {-Araç ve özel araç } \\
\text {-Toplu taşıma } \\
\text {-Yaya }\end{array}$ & $\begin{array}{l}\text { Düzen } \\
\text { - } \\
\text { Uyumluluk } \\
\text {-Devamlılık } \\
\text { - Denge }\end{array}$ & $\begin{array}{l}\text { Detaylandırma } \\
\text { - Malzeme birleşimleri } \\
\text { - Kent mobilyaları }\end{array}$ & $\begin{array}{l}\text { Bakım - Onarım } \\
\text { - Yerel yönetim } \\
\text { - Mülk sahipleri } \\
\text { - İşletmeciler }\end{array}$ \\
\hline $\begin{array}{l}\text { Erişilebilirlik } \\
\text {-mekan içinde rahat hareket }\end{array}$ & $\begin{array}{l}\text { Kimlik } \\
\text { - Odak } \\
\text { - Birlik } \\
\text { - Karakter }\end{array}$ & $\begin{array}{l}\text { Malzeme } \\
\text { - Doğal } \\
\text { - Yapay }\end{array}$ & $\begin{array}{l}\text { Kamu ve Özel } \\
\text { Hizmetler } \\
\text { - Temizlik } \\
\text { - İletişim }\end{array}$ \\
\hline $\begin{array}{l}\text { Çeşitlilik } \\
\text { - Sosyal olabilme } \\
\text { - Düzenlemelerin yeterliliği } \\
\text { - Aktivite yeterliliği }\end{array}$ & $\begin{array}{l}\text { Etki -Çekim } \\
\text {-Ölçek } \\
\text { - Uygunluk } \\
\text {-Canlılık }\end{array}$ & $\begin{array}{l}\text { İşçilik } \\
\text { - İşçilik Kalitesi }\end{array}$ & \\
\hline $\begin{array}{l}\text { Esneklik } \\
\text { - Değişen şartlara uyum sağlama } \\
\text { - Değişken, çok işlevli }\end{array}$ & & $\begin{array}{l}\text { Dayanıklılık - Sağlamlık } \\
\text { - Malzeme seçimi ve } \\
\text { özellikler }\end{array}$ & \\
\hline $\begin{array}{l}\text { Güvenlik } \\
\text { - Bireysel güvenlik }\end{array}$ & & & \\
\hline $\begin{array}{l}\text { Mekânsal bütünlük } \\
\text { - Kapalılık }\end{array}$ & & & \\
\hline $\begin{array}{l}\text { Konfor } \\
\text { - Yürüme, Oturma, Görüş, Gürültü, } \\
\text { Aydınlatma }\end{array}$ & & & \\
\hline Sürdürülebilirlik & & & \\
\hline
\end{tabular}

\section{$\underline{\text { Estetik Kalite }}$}

Düzen: Topçu Kışlası inşa edildiği dönemde kent merkezine uzaktır ve boş bir alana inşa edilmiştir. Bu sebeplerden dolayı çevreyle uyumluluk, açıklık, devamlılık, denge gibi parametreler açısından bir değerlendirme söz konusu değildir. 
Kimlik: Topçu Kışlasının yapımı, alanın değerini arttırmış ve dönemin de, alanı tanımlayacak kimliğe sahip olmasında büyük etkisi olmuştur.

Etki-Çekim: Kışla binası, dönemin ihtiyaçlarını karşılayacak biçimde inşa edilmiş, çevresiyle etkileşimi, ölçek, uygunluk göz önüne alınmamıştır.

\section{$\underline{\text { Yapım Kalitesi }}$}

Detaylandırma: Topçu Kışlası 19. yüzyılda Mağribi (mauresque) denilen Endülüs mimarlığı tarzında yapılmış, Osmanlı'ya özgü olmayan Hint ya da Rus işi soğan kubbeler yerleştirilerek inşa edilmiştir (Hasol 2012).

Malzeme: Kışla yapısına ait eldeki belgeler son derece yetersiz olmak ile birlikte gravürler, fotoğraflar yapıyı sadece kitlesel olarak tanımlamaya izin verebilmektedir (Alioğlu 2013). Bu nedenle malzeme açısından, kullanılan malzemelerin türü ve nereden getirildiği hakkında bilgi literatürde yer almamaktadır. 19. Yüzyılda alanda kagir ve apartmanlar (çok katlı yapılaşma) inşa edilmeye başlamıştır (Hatipoğlu 1994).

\section{Dayanıklılık Sağlamlık: Onarımlar} geçirmesine rağmen 100 yıl (1806 - 1925) boyunca ayakta kalabilen Kışlanın yakın çevresinde o dönemde Osmanlı Bankasına tahsis edilmiş olan barok tarzındaki konak, 1970'li y1llara kadar mevcudiyetini koruyarak dönemin yapılarının kalitesine örnek olarak gösterilebilir. Ayrıca 1800'lü yıllarda yapımı gerçekleşen tarihi birçok dini yap1, varlığını günümüzde de sürdürmektedir.

\section{5-1944 Yilına Ait Değerlendirme}

\section{Ișlevsel Kalite Kullanım ve Eylemler}

Ulaşılabilirlik: Toplu taşıma ile ulaşım elektrikli tramvay hattının haricinde özel halk otobüsleriyle sağlanmaya başlamıştır (Kırmızı ve Çalışkan 2009). Bu girişim ulaşım ağının gelişmesinde önemli adımlardan biri olmuştur. 1928'de anıtın etrafında tören alanı ile birlikte trafik akışını hızlandırmak için ring şeklinde düzenleme yapılmıştır (Hatipoğlu 1994).

Erişilebilirlik: Bu dönemde düzenlemesi yapilan meydan ve parkın her noktasına kolayca ulaşım sağlanmaktadır.

Çeşitlilik: Taksim ve Kristal gazinosu bu dönemde İstanbul'un ön plandaki eğlence mekanlarıdır. 1940'lı yıllardan sonra bölgede çeşitlilik artmıştır. Dini yapıları yanında, konsolosluk binaları, yükseköğretim için tahsis edilmiş askeri binalar, hastaneler, inşaatları başlayan büyük oteller, kültür merkezi alanı çeşitlilik sağlayan önemli yapılardır. Prost'un planı kapsaminda yer alan Harbiye Cemil Topuzlu Açıkhava Tiyatrosu bu dönemde tamamlanmıştır.

Esneklik: Meydan ve park çevresinde yeni yapılacak konutlar, spor tesisleri ve kültür merkezleriyle bir bütünlük içinde olması göz önüne alınarak planlanmıştır.

Güvenlik: Cumhuriyeti simgeleyen meydan ve park özellikle kadın ve çocuk kullanıcılar için düşünülmüştür. Bu açıdan meydanın tasarımında güvenlik kriterlerine dikkat edilmiş olacağı söylenebilir.

Mekânsal Bütünlük: Kışla binası ve bağlantılı yapıların yıkımıyla geniş bir alan elde edilmiştir. Ancak yapılar yıkılmadan önce düzenlemesi yapilan Taksim Meydanı, yerleştirilen Cumhuriyet anıtının etrafındaki alanın açılmasıyla ölçek açısından etkisini kaybetmiştir. 
Konfor: Planlanan alanlarin halka hitap etmesi açısından elemanlar, alana uygun ve konfor sağlayacak şekilde yerleştirilmiştir.

Sürdürülebilirlik: $\mathrm{Bu}$ dönemde alanda büyük fiziksel değişim yaşanmıştır. Cumhuriyetin önemli simgelerinden biri olması amacıyla kentin önemli merkezleri ve etkinlik alanlarını birbirine bağlayan bir konferans vadisinin başlangıç noktası olarak sürdürülebilirliği hedeflenmiştir.

\section{$\underline{\text { Estetik Kalite }}$}

Düzen: Park ve meydan birlikte tasarlanmiştır. $\mathrm{Bu}$ dönemde Talimhane bölgesi imar kanununa göre parsellere ayrılmış ve çevresindeki gelişmelere uygun olarak modern konut inşasına başlanmıştır.

Kimlik: Meydan hem siyasi hem de kamusal kimliğini bu dönemde kazanmıştır.

Etki - Çekim: Cumhuriyet anıtı etrafındaki yapıların yıkılmasıyla ölçek ve oran açısından etkisini kaybetmiştir. $\mathrm{Su}$ makseminin meydana bakan cephesinde kaskatlar oluşturularak görsel bir öğe olarak kullanılmıştır.

\section{$\underline{\text { Yapım Kalitesi }}$}

Detaylandırma: Meydan düz bir alana otururken, Parkın meydana bakan cephesi ile Talimhaneye bakan cephesi arasında kot farkı ile alan farklı mekanlar kazanmıştır. Ayrıca kışlanın yıkılıp Gezi Parkı yapılmasiyla dönemin Art Deco üslubunu sergileyen apartmanlar ile izgara dokuda, neredeyse birbirine eş büyüklükte parseller ile 19. yy. ikinci yarısında dünya ve ülkemizde yaygınlaşan, imar mevzuatına uygun konut yerleşimine dönüşmüştür (Emir 2008).

Malzeme: Bu dönemde yapılan binaların inşa tarzı aynıdır. Temeller, dış duvarları, tavanları ve merdivenleri betondur. Çatıları tahta zemin üzerine Marsilya kiremidi ve kısmen oluklu saç ile örtülüdür (Anonim 2011).

Dayanıklılık - Sağlamlık: Gerek meydan ve gezi parkı gerekse binalarının halen varlığını koruması, yapıların kullanım ihtiyacına yönelik olarak sadece restore edilip (Eryılmaz 1999), tekrar hizmete açılmış olması dayanıklılık ve sağlamlığını göstermektedir.

\section{4-1987 Yilına Ait Değerlendirme}

\section{İşlevsel Kalite Kullanım ve Eylemler}

Ulaşılabilirlik: Alanda, ticaret alanların sayısının artmasıyla birlikte hem araç hem de yaya trafiğinde bir artış olmuştur. İmar hareketleriyle alanların bölünmesi sonucunda tramvay hatlarının kullanımı zorlaşmış ve tramvay tamamen kaldırılmıştır. Taksimden kentin birçok farklı noktasına otobüs hatları koyulmuştur. Trafiği rahatlatmak amacıyla metro inşası çalışmalarına da başlanmıştır. Erişilebilirlik: $\mathrm{Bu}$ dönemde meydan ve çevresinin düzenlenmesi artan taşıt trafiği nedeniyle kavşak haline gelmiştir. Taşıtların alanı bu kadar yoğun bir şekilde kullanması yayaların kullanım alanlarını olumsuz bir şekilde etkilemiş, yaya kullanımlarının belirli bir alanda yığılmasina neden olmuştur.

Çeşitlilik: $\mathrm{Bu}$ dönemde meydan ve çevresinde 1977 yılı 1 Mayısından sonra resmi kutlama ve miting yapilması yasaklanmıştır. Meydan ve Gezi Parkı 1977 yılına kadar resmi törenlere ve rekreasyon amacıyla kent halkına ev sahipliği yapmıştır. Meydanın yakın çevresinde inşa edilen Atatürk Kültür Merkezi (2000 yılına kadar hizmet etmiştir), Harbiye Cemal Reşit Rey konser salonu bu dönemde hizmete girmiştir. 
Esneklik: Gelişen turizm ve ticaret faaliyetleri, alanın taşıma kapasitesinin üzerinde kullanımına neden olmuştur. Meydan ve park bu hızlı gelişmelere uyum sağlayamamıs ve olumsuz etkilenmiştir.

Güvenlik: Alanın imara açılmasından sonra hızlı ve kontrolsüz bir şekilde yapılaşması, göç ve ulaşımın plansız gelişmesi ile güvenlik olumsuz etkilemiştir.

Mekânsal Bütünlük: Alan imara açılmasından sonra düzensiz ve kontrolsüz bir şekilde yapılaşmıstır (Yıldız 2007). 1980'li yıllarda tarihi yapiların kat yüksekliğini geçen binaların, üst katları yıkılarak tarihi binaların seviyesine çekilip kontrol altına almaya çalışılmıştır (Kırmızı ve Çalışkan 2009). Ayrıca Tarlabaşı Caddesi üzerinde meydanla bağlantılı bir alan yaratmak amacıyla yıkımlar yapılmış ancak bu yıkımlar iki bölgeyi birbirinden daha çok koparmıştır (Url 1).

Konfor: Artan nüfus ve buna bağlı olarak trafik yoğunluğu ile gürültü kirliliği oluşmuş ve alanın konforunu negatif yönde etkilemiştir. Kullanıcı sayısının artmasıyla oturma birimleri ve yürüyüş yolları da yeteriz kalmıştır.

Sürdürülebilirlik: Bu dönemde alan bütün olumsuz etkilere rağmen odak noktası kimliğini koruyarak, gelişen ulaşım ağı ve artan kullanıcı sayısıyla popülerliğini daha da arttırarak varlığını korumuştur.

\section{$\underline{\text { Estetik }}$}

Düzen: Çevresinde artan konut sayısı ve yapı çeşitliliği düzenlenmelerin yapıldığı ilk yıllara oranla uyumluluk, açıklık ve denge açısından estetik kaliteyi olumsuz olarak etkilemiştir. - Kimlik: Alan kamusal ve siyasi kimliğinin yanı sıra ticaret alanların sayısının artmasıyla ticari açıdan da bir kimlik kazanmıştır. Ulaşım açısından odak noktası haline gelmeye başlamıştır.
Etki - Çekim: Bölgede sayısı artan ticaret ve eğlence mekânları alanı bu dönemde etki ve çekim merkezi haline getirmiştir.

\section{$\underline{\text { Yapım Kalitesi }}$}

Detaylandırma: Meydan ve park alanında bu dönem içinde değişiklik olmamıştır.

Malzeme: $\mathrm{Bu}$ dönem bilgiler ışığıda kullanılan malzemelerde değişiklik olmadığı belirlenmiştir.

Dayanıklılık Sağlamlık: Önceden bakımlı olan park ve meydan ihmal edilmiş, 1990'l yıllarda park çok bakımsız, meydan ise metro inşaatının başlaması nedeniyle bozulmuştur (Gültekin 1996).

\section{7-2014 Yilına Ait Değerlendirme}

\section{İslevsel Kalite Kullanım ve Eylemler}

Ulaşılabilirlik: 2011'de tamamlanan Taksim-Haciosman Metro hattiyla bu güzergahta bulunanların meydana ulaşımı kolaylaşmıştır. Ayrıca Taksim Meydanı işyeri, okul vb. servislerinin kalkış noktası haline gelmiştir (Yalçın 2011).

Erişilebilirlik: Taksim Meydanı ve çevresinin, bir çok bağlantı ve ulaşım alternatifleriyle (hafif raylı ve tramvay füniküler metro sistemi) destekleniyor olması alana erişimi kolaylaştırmaktadır (Özaydın 2012). Bunun yanında meydanda yaya trafiğini bölen yollar, kullanıcılar için zorluk yaratmaktadır.

Çeşitlilik: Günümüzde meydan devlet ve sivil toplum kuruluşlarının kutlama törenleri, eğlence, çeşitli konularda mitingler, yürüyüssler gibi etkinliklere ev sahipliği yapmaktadır.

Esneklik: Meydan ve çevresi, yap1 adalarının ve yoğun araç trafiğinin gölgesi altında kalmış, yapılması planlanan 
uygulama çalışmalarında mekanların toplumsal açıdan önemleri ve yapılacak tasarımlarla uyum içinde olmaları göz ardı edilmiştir.

Güvenlik: İnsanların buluşma ve dağılma noktası ve kalabalığın fazla olması nedeni ile güvenlik hizmetleri yetersiz kalmaktadır.

Mekansal Bütünlük: Yapıların plansız kat yükseklikleri nedeniyle alandaki kapalılık oranı artmıştır. Ayrıca meydan, çevresindeki yapılarla bir uyum sağlayamamaktadır.

Konfor: Kısmen araç trafiği yer altına alınsa da gürültü kirliliği hala mevcuttur. Meydanda yetersiz kalan çöp kutuları, oturma birimleri vb. donatı elemanları, konfor sağlayacak nitelikte değildir.

Sürdürülebilirlik: Talimhane'de, turizm amaçlı dönüşüm yaşanırken yeni inşa edilen yapılar kentlinin kentlileşme sürecini ve kentin biçimsel hafızasını yok ederek alanın özelliğini kaybetmesine neden olmaktadır (Emir 2008). Taksim Meydanı ve çevresinde yapılan yeni değişimler, bölgenin tarihi açıdan sürdürebilirliğini tehdit etmektedir.

\section{$\underline{\text { Estetik }}$}

Düzen: Çevresindeki yapıların bilinçsiz restorasyonu ve yeni yapilarda belirli bir kuralın benimsenmemesi nedeniyle (kat yüksekliği, cephe birliği vb.) meydan çevresindeki yapılar oldukça düzensiz bir hale gelmiştir. Bu da alandaki devamlılık ve dengeyi olumsuz etkilemiştir.

Kimlik: Son yıllarda kullanıcı profilinin çeşitlenmesi, mekanı oluşturan fiziksel yapının bilinçsiz restorasyonuyla tarihi dokunun zarar görmesi mekansal kimliği olumsuz etkilemiştir.
Etki - Çekim: Trafiğin yer altına alınması ve meydanda yapilan yayalaştırmayla yaya kullanım alanları artmıştır.

\section{$\underline{\text { Yapım Kalitesi }}$}

Detaylandırma: Gezi Parkı 1991-1992 yılları arasında revize edilmiştir (Gültekin 1996). 1989- 1994 yilları arasinda parkta İ.B.B. tarafından yapılan yenileme çalışması ile yaya sirkülasyonları rahatlatılmış, sosyal aktiviteler için alanlar planlanmıştır (Eryılmaz 1999). Gezi Parkı'nda ise kentsel mobilyalarda yenilemeler gerçekleştirilmiştir. Ayrıca meydan için, Tarihi Maksemi'nin, bir şelale görünümü kazanması, meydana ses ve müzik sistemli gösteri havuzu gibi projeler öngörülmüsstür (Gökgür 2008 ve Yalçın 2011). Meydan ve çevresinde kullanılan malzemeler dönemin kimliğini yansıtacak şekilde seçilmemiş ve kent mobilyaları kullanıcı gereksinimlerini karşılamaya yetecek sayıda değildir. 1994 yılında Taksim Cami projesi gündeme gelmiş ve su maksemi bitişiğinde imar planı değişikliği yapılıp onaylanmış ancak tartışmalara neden olduğu için uygulamaya geçilmemiştir.

Malzeme: Mekanın tarihi dokusunu yansitan malzemeler kullanılmamıştır. Taksim Meydanı, zafer anıtının bulunduğu alan parke taş döşeme, tramvay aksı dişında kalan alanlar ise kilitli beton parke ile kaplanmıştır. Taksim Meydanı'ndan İstiklal Caddesine yönelinen güzergahta zemin, taş plaklarla kaplanmıştır (Yalçın 2011).

Dayanıklılık-Sağlamlık: Onarım yapılan yerlerde alanın orijinal döşeme malzemesi kullanılmamıştır. Ayrıca işçilik ve altyapı hatalarından dolayı döşemelerde çökmeler ve sorunlar vardir. 


\section{Bakım ve Hizmet Kalitesi}

Düzenli Bakım - Onarım: Alanda belediyenin bakım hizmetleri kapsamında bakım onarım çalışmaları yapılmakta, ancak döşemeler ve fonksiyon elemanlarındaki sorunlardan çalışmaların yetersiz olduğu anlaşılmaktadır.

Kamu ve Özel Hizmetler: Temizlik ve yol hizmetleri çalışmalarını belediye yapmaktadır. İletissim konusunda yine belediyenin alanda belli noktalarda iletişim noktalarından bilgi almak mümkündür.

\section{Ekonomik Kalite}

Zamanla Sağlanan Gelir: Özellikle son 20 yılda alanın çevresinde ticaret ve turizm açısından artan işletmeler, bölgenin ekonomik değerini arttırmıştır. Alanın çevresindeki yapıların büyük çoğunluğu iş yeri veya otel olarak hizmet vermeye başlamıştır.

\section{Mekansal Kalite Parametrelerine Göre Değerlendirme Ölçütleri}

Gibson'a (1968) göre; mekânsal kalite, özünde göze çarpan farklılıklar arka plandakiler ile ilgilidir: Yani bu farklılıkların alanda yer alan düzenin yapım aşamasındaki durumundan itibaren başlayıp değişikliklere uğraması mekânsal kalitenin okunabilirliğini sağlayacağını belirtmiştir. Bu yüzden araştırma alanının geçmişten günümüze gelene kadar geçen evredeki değiş̧iklikler, haritalar üzerinde okunabilirliği mekânsal kalite parametrelerinde verilen ölçüt değerlerine göre irdelenmiştir.

Çalışmada mekânsal kalite parametrelerinde ortaya konan bilgiler ışığında ölçütlere ' $+2,+1,-1,-2$ ' değerleri verilerek olumlu ve olumsuz etkenler tespit edilmeye çalışılmıştır. ' +2 ' değeri istenen özelliklerin sağlanmış olduğunu, '-2' ise istenen özelliklerden hiçbiri ya da bir kaçının sağlandığı durumları ifade etmektedir. Sonuç olarak yıllara göre alınan değerler toplanarak, en yüksek değer mekânsal kalite bağlamında istenen özelliklere en yakın düzen olarak belirlenmeye çalışılmıştır.

Burada amaç 1806 yllından bu yana yapılan planlar dahilinde meydan ve çevresinde gerçekleşen düzenlemelerin kent kimliğine etki ve katkılarının niteliğidir (Tablo 2). Tablodan da anlaşılacağı üzere olumlu etkenlerin yer aldığı dilim 1925-1944 yılları arasında ki dönemi göstermektedir. 
Tablo 2: Mekansal Kalite Parametrelerine Göre Değerlendirme Ölçütleri

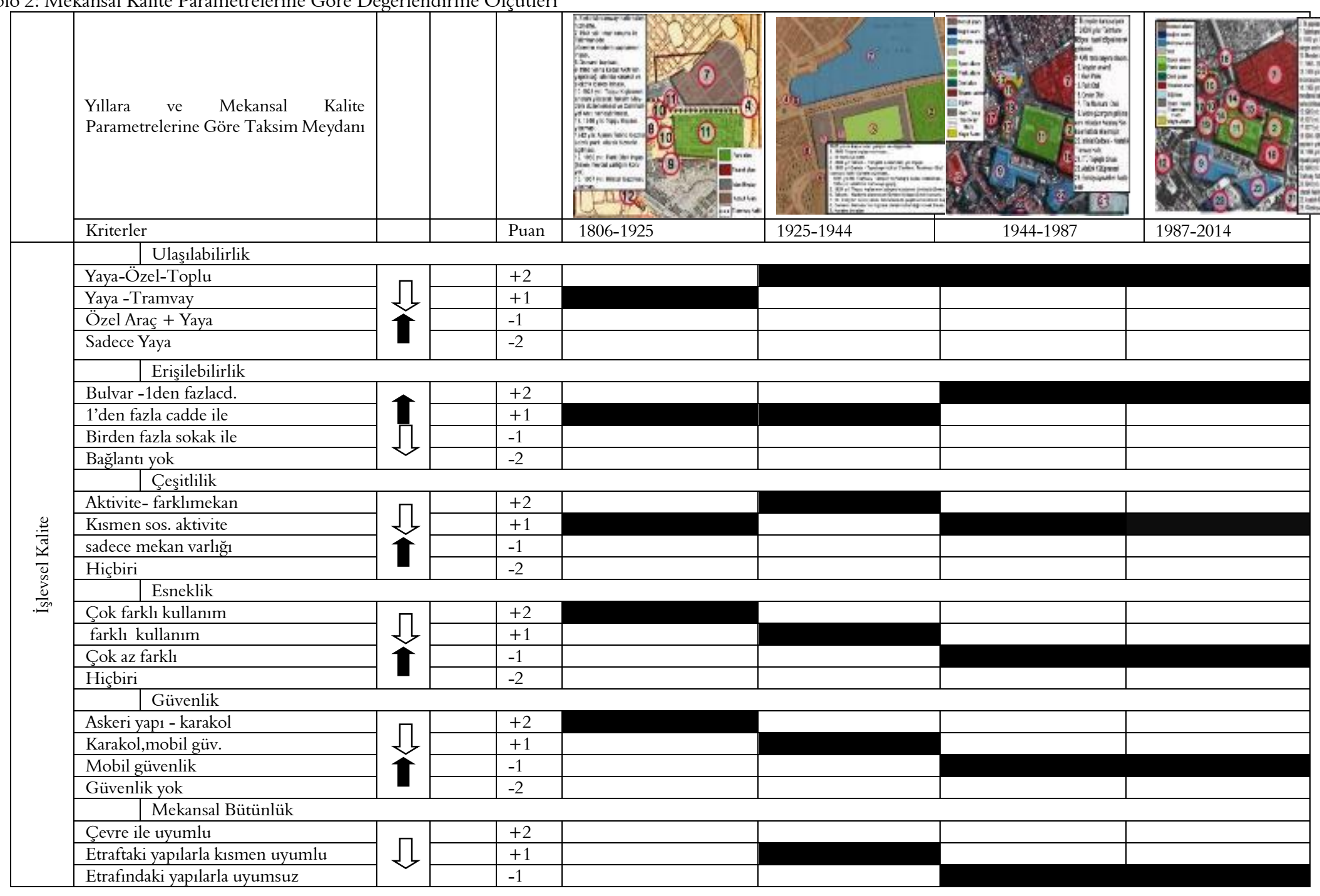

143|A C Ü Orman Fak Derg 15(2): 132-148 


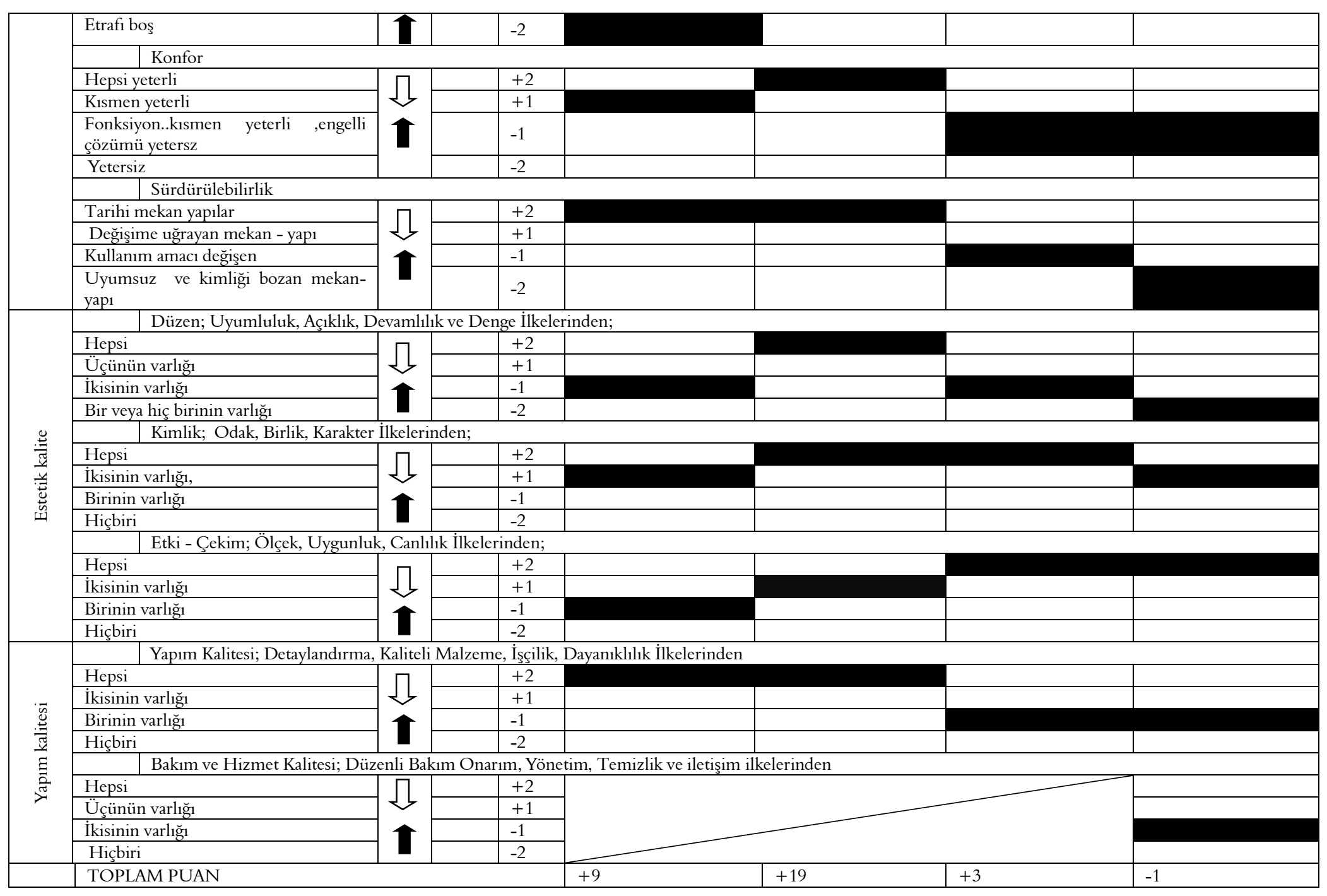




\section{TARTIŞMA VE SONUÇ}

Günümüz Taksim meydanında, küreselleşme süreçleri içerisinde kent kimliği yok olma noktasındadır. Bu süreçler içerisinde kent mekanını doğru algılayıp, var olan kent kimliğinin yok olmasının önüne geçilmeye çalışılmalıdır. Ancak, bu yapilırken taklitten uzak, akılcı yöntemler izlenmelidir. Tarihsel süreç içerisinde değişime uğrayan Taksim meydanının kimlik değişimi mekansal kalite parametreleri yöntemiyle incelenerek çeşitli sonuçlar elde edilmiştir. $\mathrm{Bu}$ sonuçlar;

Geçen süreç içerisinde ulaşım sorununun düzenlenmeye çalışılmasina rağmen olumlu bir etkinin olmamas1,

Yapilan uygulamaların ve onarımların mekansal kaliteyi geliştirmek yerine, olumsuz yönde etkilediği,

İlk öneri projede yapılması düşünülen Topçu Kışlasının toplum hafizasında ve güncel kullanım alanlarında ihtiyaç duyulan ve özlenen bir yapı olmadığı, bu konuda farklı disiplinlerdeki uzmanların görüşlerinden de anlaşılmaktadır. Okar (2013)'e göre; Rekonstrüksiyonun tercih edilen bir yöntem olmadığını, bunun nedeninin özgün yapının geri gelmeyeceği, sadece bir kopyasının olacağı, parkın kamusal faydasının yapılacak taklitten çok daha fazla olduğunu belirtmektedir. Bunun yanında kışla binası, kent içinde tecritli bina tehlikesi yaşatacağ (Şekil 6). Turanalp Gezgin (2013); 70 yıllık tarihiyle kent belleğinde önemli bir yere sahip olan Taksim Gezi Parkı'nın tarihsel ve korunmaya değer varlıklarından biri olduğunu ve hatta ortadan kaldırılması bir yana, restore edilerek, asli özellikleri iade edilmesi gerektiğini vurgulamıştır.

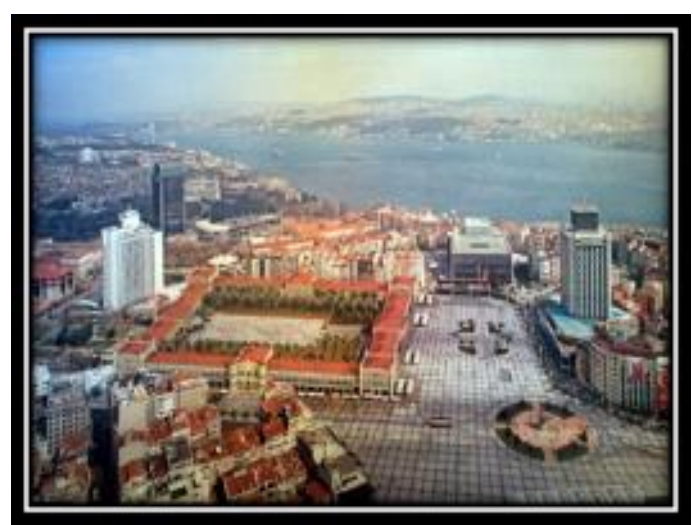

Şekil 6: Yenileme projesi kışla bina görüntüsü (Gürsel 2014)

Araştırmanın çıkış noktası, özellikle 1806 yılından bu yana yapılan planlar dahilinde meydan ve çevresinde gerçekleşen düzenlemelerin kent kimliğine etki ve katkılarının niteliğidir. Mekânsal kalite parametreleri analizi ve değerlendirme ölçütlerine göre 1925-1944 yılları arası meydan ve çevresinin kendine özgü niteliklerini taşıdığı, araştırmanın dikkat çekici sonuçları arasındadır.

Taksim Meydanı ve çevresinde ulaşım sorunun çözümü için 1930'lu yıllarda Prost tarafindan altgeçit öneri planları çizilerek teklif edilmiştir. Ancak çalışmalar uygulamaya geçilmemiştir. 1987 yılı çalışma planında Büyükşehir Belediyesi hem ulaşım sorununa çözüm getirmek, hem de meydanda tekrar düzenleme yapmak amacıyla bir yarışma düzenlemiştir. $\mathrm{Bu}$ proje kapsamında Taksim meydanında araç trafiğinin yerin altına alınması, Tarlabaşı ve Taksim meydanın bağlantısının sağlanması amaçlanmıştır. Proje Yarışması yapılmış ancak uygulamaya geçilmemiştir.

Günümüzde, Taksim Meydanı ve çevresinde araç ve yaya ulaşımı, geçen süreçte daha büyük bir kaosa dönüşmüştür. Çözüm için araç trafiğinin yerin altına alınması ve meydanın yayalaştırılması planlanmış ve uygulamaya geçilmeye 
başlamıştır. Yenilenme projesinde en son öneri proje ile çevredeki görüş açısının genişlediği ve ışınsal dağılımın, yeni haliyle Harbiye ve Gümüşsuyu yönüne doğru yönelerek meydan özelliğini yitirmesine neden olmuştur. Bu kadar büyük bir beton, meydanın algilanabilirliğini ve merkeziyetçi algısını kırmıştır. Anıt, meydana iliştirilmiş sanatsal bir obje halini almıştır. Halen devam eden çalışmalar sonunda, şuan için yapılması düşünülen projede (Şekil 7) meydana getirilecek boylu ağaçların kök sistemi belli bir hacme ve derinliğe ihtiyaç duyacaktır. Bu durum zemin altındaki fonksiyonlardan dolayı mümkün olmayacak, yukarıya doğru toprak alanı arttırmaları gerekecektir. Bu da göz seviyesindeki perspektifi ve bütüncül algılamayı bölecektir (Şekil 8).

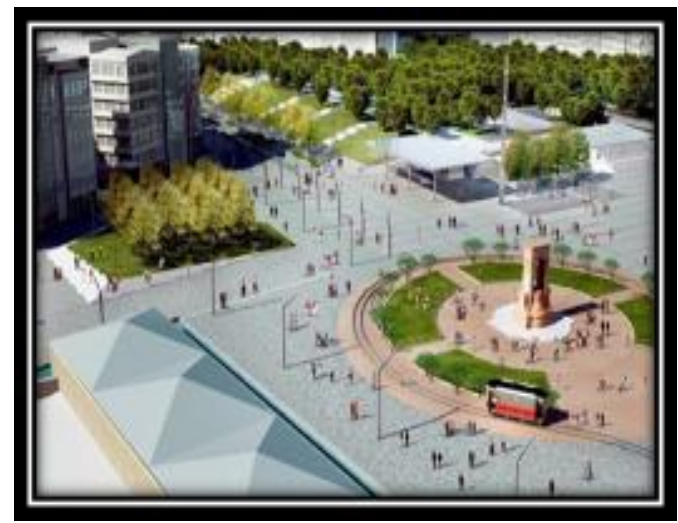

Şekil 7 Son dönem öneri proje, anıt çevresı (Gürsel 2014)

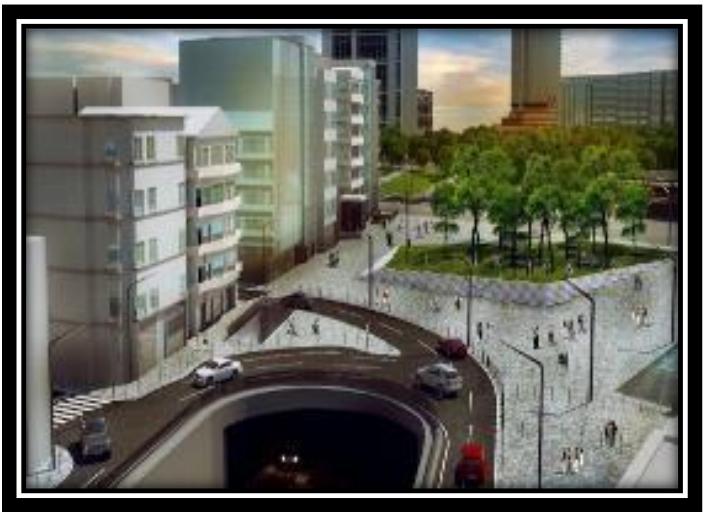

Şekil 8: Öneri proje,trafik düzeni görüntüsü (Gürsel 2014)
Kentsel mekanın biçimlendirilmesi süreçlerinde günümüzde yapilmaya çalışılan planlara bakıldığında kentsel bütünlüğü bozan, kente karakter kazandırmaktan uzak bir yapılanmaya doğru yol aldığı görülmektedir.

Kentsel mekana nitelik kazandıracak planlama araçlarının üretilmesinde, bireysel üretime odaklanan planlama anlayışından öte birlikteliğe öncelik verecek, vizyon ve stratejilerle pekiştirmeyi hedefleyen bir yaklaşımla ele alınması gerekmektedir. Daha önce yapilan yayalaştırma projeleri de ele alınarak, kamuoyunun desteği göz ardı edilmeden kimliğini kaybetmeye yüz tutmuş meydan tekrar kimliğine kavuşturulmalıdır.

\section{KAYNAKLAR}

Akpınar YI, Gümüş K (2012) Taksim Dün-Bugün: İdeolojik Bir Okuma. TMMOB Mimarlar Odası 28:38-46

Alioğlu F (2013) Rekonstrüksiyon ya da Yeniden Yapma, Hangi Yapı İçin? Taksim Topçu Kışlası İçin Bir Değerlendirme. Megaron Journal Cilt Vol. 8 - Sayı No: 1 ,Sayfa 1-7

Altuğ Tİ (2010) Kentsel Tasarımda Fiziksel Kent Kimliği Kodlarının Oluşturulması. E. Ü. Fen Bilimleri Enstitüsü Doktora Tezi,296 sayfa İzmir.

Altunbaş U (2006) Kent Merkezlerinde Yayalaştırmanın İşlevsel Değişim Üzerine Etkileri: İstiklal Caddesi Örneği. İ.T.Ü Fen Bilimleri Enstitüsü Yüksek Lisans Tezi ,92 sayfa, İstanbul.

Anonim 2012. Taksim Meydan Düzenlemesi, TMMOB Peyzaj Mimarları Odası Meydan Düzenlemesine ilişkin Değerlendirmeler, İstanbul

Anonim (2001) Jacques Pervititch Haritaları. Axa Oyak Holding AŞ. Tarih Vakfi. ISBN 9757306-73-8, Alman Konsolosluğu Kitaplığı, İstanbul

Anonim (2000) Project for Public Spaces (PPS) How to Turn a Place Around: A Handbook of Creating Successful Public Spaces. Project for Public Spaces, New York

Anonim (1987) Taksim Meydanı Kentsel Tasarım Proje Yarışması. İstanbul Büyükşehir Belediyesi, Belediye Arşivi, İstanbul

Bayram B (2007) Kamusal Mekan Kalitesinin Yükseltilmesinde Yöntemler ve Kamusal 
Sanatın Rolü. İ.T.Ü Fen Bilimleri Enstitüsü Yüksek Lisans Tezi, 169 sayfa ,İstanbul.

Çalışkan M (2011) Kamu Yararı Bağlamında Kamusal Mekanlarda Bir Yayalaştırma Örneği Eminönü Tarihi Yarımada Yayalaştırma Projesi. İ.T.Ü Fen Bilimleri Enstitüsü Yüksek Lisans Tezi, 166 sayfa, İstanbul,

Çöl Ş (1998) Kentlerimizde Kimlik Sorunu ve Günümüz Kentlerinin Kimlik Derecesini Ölçmek İçin Bir Yöntem Denemesi. M.S.Ü. Fen Bilimleri Enstitüsü Yüksek Lisans Tezi, 316 sayfa İstanbul

Deniz TK (2011) Kent kimliği üzerine bir araştırma: Konya örneği. Uluslararası İnsan Bilimleri Dergisi (8)2: 1048-1072

Eryılmaz S (1999) Kamu Kullanımlı Kentsel Açık Alanların Tarihsel Süreç İçerisinde Gösterdikleri Yapısal Değişimlerin İrdelenmesi İstanbul Örneği. İ.T.Ü Fen Bilimleri Enstitüsü Yüksek Lisans Tezi,144 sayfa İstanbul.

Emir S (2008) Değişen Sokak Cepheleri Üzerine Bir Araştırma Talimhane Örneği. Y T.Ü. Fen Bilimleri Enstitüsü Yüksek Lisans Tezi, 97 sayfa İstanbul.

Gültekin H (1996) İstanbul'da Meydanların Peyzaj Açısından Değerlendirilmesi. İ. Ü. Fen Bilimleri Enstitüsü Yüksek Lisans Tezi, sayfa 137, İstanbul.

Gürsel D (2014) Taksim Meydanı'nın Yeni Görselleri Ortaya Çıtı http://www.arkitera.com/haber/19644 Erişim Tarihi: 06.02.2014

Gürsel E (2012) İstanbul Kenti En Önemli Meydanını Kaybedebilir. Mimarlık Dergisi 364 ,Mart-Nisan sayısı .

Hasol D (2012) 29 Mart Cumhuriyet Gazetesi, http://ismd.org.tr/author/dogan-hasol/. Erişim 17 Kasim 2013

Hatipoğlu H (1994) Kentsel Yapılaşmış Çevrenin Oluşumunda Dış Mekan Yaşantısının Yeri ve İşlevi İstanbul Taksim Meydanı. İ.T.Ü Fen Bilimleri Enstitüsü Yüksek Lisans Tezi,sayfa 141 İstanbul.

İnceoğlu M (2007) Kentsel Açık Mekânların Kalite Açısından Değerlendirmesine Yönelik Bir Yaklaşım: İstanbul Meydanlarının İncelenmesi. Y.T.Ü. Fen Bilimleri Enstitüsü, Doktora Tezi, 379 sayfa ,İstanbul.

Karagözlü C (2013) Kentin Düğüm Noktaları: Meydanlar.

http://cemkaragozlu.blogspot.com.tr/ Erişim 21 Ocak 2014

Kırmızı Z, Tunalı ÇF (2009) İstanbul ve Ulaşım Zaman Dizini. Cinius Yayınları, İstanbul

Kozar,C.(2012)Hayal-Et Yaplar Sergisi'nde TaksimKışlasıhttp://www.arkitera.com/gorus/i ndex/detay/hayal-et-yapilar-sergisi-ndetaksimkislasi /268 Erişim Tarihi: 18.02.2014
Kuban D (1970) 100 Soruda Türkiye Sanatı Tarihi. Gerçek Yayınları, İstanbul

Lynch K (1960) The Image of the City. The M.I.T Press, Cambridge

Lynch K (1990) City Sense and City Design: Writings and Projects of Kevin Lynch. MIT Press, Cambridge

Okar E (2013) Meslekten Kentliler Gezi Parkı Hakkında Neler Söyledi?. http://www.arkitera.com/haber/index/detay/m eslekten-kentliler-gezi-parki-hakkinda-nelersoyledi_/15379. Erişim 21 Ocak 2014

Oktay D (2007) Kentsel Kimlik ve Canlılik Bağlamında Meydanlar: Kuzey Kıbrıs'ta Bir Meydana Bakış. Mimarlık Dergisi 334 Erişim 1 ekim.2014

Özaydın G (2012) Taksim'in Üstü Altına İniyor. Mimarlık Dergisi 364 mart -nisan sayısı

http://www.mimarlikdergisi.com/index.cfm erişim Erişim 2 ekim 2014

Özer MN, Ayten MA (2005) Kamusal Odak Olarak Kent Meydanları. Planlama 2005/3 :96-103

Rapoport A (1977) Human Aspects Of Urban Form :Towards A Man- Environment Approach To Urban Form And Design. Pergamon Press, Oxford

Sağsöz VA, Zorlu T (1996) Kent KimliğiKimliksizliği ve Tasarımcının Rolü- Trabzon Kentinde Bir Araştırma. Mimarlar Odası Yapı ve Yaşam Dergisi 96

Turanalp GML (2013) Meslekten Kentliler Gezi Park1 Hakkında Neler Söyledi http://www.arkitera.com/haber/index/detay/m eslekten-kentliler-gezi-parki -hakkinda-nelersoyledi_/15379 Erişim 21 Ocak 2014

Ulu A, Karakoç İ (2004) Kentsel Değişimin Kent Kimliğine Etkisi. Planlama Dergisi 2004/3: 5966

Url1:BeyoğluBelediyesi,Dönüşüm,http://www.beyo glubuyukdonusum.com/tarlabasi/detay/Tarihc e/48/181/0 Erişim Tarihi:05.02.2014 istanbul

Url2:İstanbul Büyük Şehir Belediyesi http://sehirrehberi ibb.gov.tr/map.aspx Erişim Tarihi: 08.02.2014

Ur13: Google map https://www.google.com/maps/place/Taksim/ @ 41.036871,28.98666,777m/data=!3m2!1e3!4 b1!4m2!3m1!1s0x14cab7653c7b483b:0x12651 0417c7cd30f Erişim Tarihi: 08.02.2014

Voordt VD (2005) Architecture in Use: an Introduction To The Programming Design and Evaluation of Buildings. Architectural Press, Amsterdam

Yalçın A (2011) Taksim Meydanı Ve Çevresinin Bir Kamusal Alan Olarak Tüm Kullanıcılara Yönelik Erişilebilirliğinin İrdelenmesi. BAÜ Fen Bilimleri Enstitüsü Yüksek Lisans Tez isayfa 220, İstanbul. 

Meydanı)

YildırımB(2014)http://www.arkitera.com/gorus/inde $\mathrm{x} /$ detay/sehrin-en-onemli-meydani-boyle-mitasarlanmali /464 Erişim 06 Şubat 2014

Yıldız A (2007) Tarihsel Birikime Sahip Kentsel Açık Alanların Dinamizmi İstanbul Kent Örneği;
Beyazit, Sultanahmet ve Taksim Meydanı. İ.T.Ü Fen Bilimleri Enstitüsü Yüksek Lisans Tezi, 90 sayfa, İstanbul.

Zucker P (1959) Town and Square. Columbia University Press, New York 